\title{
Küllerinden Doğan Bir Tıbbi Uygulama: Müzik Terapi
}

\author{
A Medical Practice That is Rising From the Ashes: Music Therapy
}

Levent ÖZTÜRK ${ }^{1}$, Hanefi ÖZBEK²

ÖZ

Türkiye'de son on yıldır bir tıbbi uygulama yönteminin giderek daha fazla kendini ortaya çıkardığı, daha çok konuşulduğu ve bu konuya özel müstakil bilimsel toplantıların düzenlendiğini izliyoruz. Tüm bu gelişmeler yaşanırken sürekli vurgulanan bir nokta var: o da bu uygulamanın geçmișimizde var olduğu ve bir nedenle zamanın belli bir döneminde terk edildiği gerçeğidir. Sözünü ettiğimiz uygulama "müzik terapi” olarak adlandırılmaktadır. Müzik terapi 1850'lere kadar Anadolu coğrafyasında yaklaşık bin yıl süreyle uygulanmış ve sonra terk edilmiştir. 2000'li yılların başlarında başlayan ve giderek ağırlı̆̆ını arttıran çalışmalarla 2016 yılının son ayı içinde Sağlık Bakanlığı tarafindan verilmeye başlanan müzik terapist sertifikaları ile resmi olarak yeniden doğmuştur. $\mathrm{Bu}$ doğumun, hararetini hiç kaybetmediği anlaşılan bir mazinin külleri üzerinden gerçekleştiğini söylemek herhalde çok hatalı olmayacaktır. Müzik terapinin erken dönem kaynakları arasında El-Kindi, Farabi, İhvan-1 Safa, İbni Sina ve Şuuri Hasan Efendi sayılabilir. Müzikterapi alanında Türkiye'de asıl ivmelenmenin 2000'li yıllarda başladığı söylenebilir. Yayınlanan kitaplar, doktora ve yükseklisans tezleri bunun göstergesidir. İlk defa 2008 yılında Trakya Üniversitesi Tıp Fakültesi'nde müzikterapi seçmeli ders olarak açılmıştır. 2014 yılından itibaren de İstanbul Medipol Üniversitesi Tıp Fakültesi'nde ders müfredatına girmiştir. 27 Ekim 2014 tarihinde yayınlanan Geleneksel ve Tamamlayıcı Tıp Uygulamaları Yönetmeliği ile müzikterapi alanında ilk yasal düzenleme gerçekleşmiştir. 2016 yılında Sağlık Bakanlığı tarafindan ilk müzikterapist sertifikaları verilmeye başlanmıştır. Müzik terapi uygulamaları yaşadığımız coğrafyada 800'lü yıllardan itibaren yazılı kaynaklara girmiş ve 1800'lü y1llara kadar dönemin tıp ve sağlık görüşleri içinde gelişerek, dönüşerek kullanılagelmiştir. 1850'li yıllarda terk edilen veya unutulan bu uygulamalar son on yıl içinde özellikle yoğunlaşan çalışmaların katkısı ve Devlet kurumlarının bu konudaki desteği ile yeniden başlatılmış, âdeta küllerinden yeniden doğmuştur.

Anahtar Kelimeler: Müzikterapi, Türkiye, yasal düzenlemeler, kurumlar

Levent ÖZTÜRK (®),

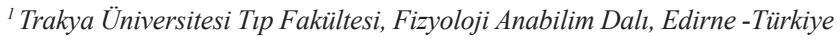
e-posta:leventozturk@trakya.edu.tr

Hanefi ÖZBEK

${ }^{2}$ Ístanbul Medipol Üniversitesi, Tibbi Farmakoloji Anabilim Dall, İstanbul-Türkiye

\begin{abstract}
It is evident that a type of medical practice has been rising in Turkey within the last decade. It has been discussed in scientific meetings devoted to this specific topic. Besides all these progress, a point of view has always been stressed: this special medical practice existed in the past history of our country but somehow it has been abandoned. It is music therapy. It had been applied for thousand years in anatolia until 1850ies. By the beginning of 2000, efforts led to rebirth of music therapy and Ministry of Health started to licence professionals in 2016. It would not be wrong to say that music therapy rised out of the ashes of history which were smoldering. The early references of music therapy include El-Kindi, Alfarabius, Brethren of Purity, Avicenna and Şuuri Hasan Efendi. It can be said that the main impetus for music therapy started to accelerate during the years of 2000s in Turkey. Published books and dissertations are surrogate measures of this acceleration. For the first time, in 2008, music therapy was included to curriculum as elective course in Trakya University Faculty of Medicine. It was also included to undergraduate curriculum in İstanbul Medipol University Faculty of Medicine by the year of 2014. The first regulation was issued on October 27, 2014 under the title of Traditional and Complementary Medicine Bylaw. In 2016, Ministry of Health started to give licence to medical professionals as music therapists. Written documents show that music therapy practice was present in this geography since the years of $800 \mathrm{~s}$ and it was used until 1800s. Music therapy was abandoned in 1850ies, but in the last decade, it rised from the ashes by efforts of academicians, music and medical professionals, and support of governmental institutions.
\end{abstract}

Keywords: Music therapy, Turkey, legal regulations, institutions

\section{GİRIŞ}

Türkiye'de son on yıldır bir tıbbi uygulama yönteminin giderek daha fazla kendini ortaya çıkardığı, daha çok konuşulduğu ve bu konuya özel müstakil bilimsel 
toplantıların düzenlendiğini izliyoruz. Tüm bu gelişmeler yaşanırken sürekli vurgulanan bir nokta var: o da bu uygulamanın geçmişimizde var olduğu ve bir nedenle zamanın belli bir döneminde terk edildiği gerçeğidir. Sözünü ettiğimiz uygulama "müzik terapi” olarak adlandırılmaktadır. Daha müzik terapinin ne olduğu, ne işe yaradığı ve sağlık alanında kullanım endikasyonları tam olarak anlaşılamadan hızla bazı sorunlar ve tartışmalar da gündemdeki yerini aldı: Müzik terapi kimler tarafından uygulanmalı ya da uygulanabilir? Müzik terapi gerçekten de bir tedavi şekli midir? Müzik tedavi eder mi? Müzik terapi bir alternatif tıp uygulaması mıdır? Uygulanacak müzik türü ne olmalıdır? Türkiye dışındaki ülkelerde yapılan uygulamalar bizim için de geçerli midir? Eğitimi kimler tarafindan verilecek ve sertifikasyon nasil olacak? Soru listesini daha da uzatmak mümkün. Tüm bu konular zaman zaman ulusal basında ve görsel medyada yer aldı. Daha yavaş ilerleyen ise konunun bilimsel ya da kanıta dayalı tıp zemininde tartışılması oldu. Bu yazıda son 10 yıldır yaşanan bir doğum süreci, bu süreci hazırlayan faktörler ve kritik noktalar verilerek özetlenmeye çalışlacaktır. Müzik terapi 1850'lere kadar Anadolu coğrafyasında yaklaşık bin yıl süreyle uygulanmış ve sonra terk edilmiştir. 2000'li yılların başlarında başlayan ve giderek ağırlı̆̆ını arttıran çalışmalarla 2016 yılının son ayı içinde Sağlık Bakanlığı tarafından verilmeye başlanan müzik terapist sertifikaları ile resmi olarak yeniden doğmuştur. Bu doğumun, hararetini hiç kaybetmediği anlaşılan bir mazinin külleri üzerinden gerçekleştiğini söylemek herhalde çok hatalı olmayacaktır. $\mathrm{Bu}$ külleri eşelemek ve müzik terapi geleneğimizin beslendiği kaynakları ortaya çıkarmak gerekmektedir. Konunun ilgililerini bekleyen bir başka görev de bu mirasın üzerinde kanıta dayalı müzik terapi uygulamalarını geliştirmek ve kurumsallaştırarak sağlık sisteminin bundan yararlanacağı kanalları oluşturmaya katkıda bulunmaktır.

\section{Müzik terapi geleneğimizin erken dönem kaynakları}

Bilim dallarının tasnifi bize eski dönem bilim adamlarının müziği nerede konumlandırdığ 1 konusunda ipuçları sağlayacaktır. Müzik terapi konusunda da yazılı eser bırakan Farabi, İhvân-1 Safa ve İbni Sina, müziği riyazî bilimler adıyla bilinen matematik bilimleri içinde değerlendirmişlerdir (Cihan 2000). Riyazî bilimler temelde dört alt başlık içermektedir: Aritmetik, geometri, astronomi ve müzik. Buradan anlaşılacağı gibi müzik aslında bir matematik uğraşısı olarak görülmüştür. $\mathrm{Bu}$ noktada bir parantez açılacak olursa, bin yıl önce matematik çalışmalarının bir alanı olan müziğin günümüzde sadece bir sanat dalı olarak görülmesi ve özellikle üniversite öncesi eğitimde matematiğe yönlendirilen çocuklarımızın aynı hevesle müziğe yönlendirilmemesi, müzikle ilgilenen çocuğun matematik ve fenden uzaklaşacağının düşünülmesi tuhaf bir çelişkidir. Birazdan isimleri sayılacak olan filozof ve bilim adamları müzik teorisi ile ilgilenmiş ve bu konuyu istisnasız hepsi işlemiştir.

\section{el-Kindî (796 - 874)}

Müzik terapi konusunda ilk yazılı izleri El Kindi (796 874)'nin müzik risalelerinde görüyoruz. Müzik üzerine on adet risale yazan El Kindî, udun dört teli ile diğer dörtlemelerin (dört mevsim, dört element, vücudun dört sıvısı, rüzgârların yönü, ayın evreleri vb) ilişkili olduğunu ileri sürmüştür (Adamson 2007). El Kindî’ye göre udun telleri vücudun belli sıvılarına etki eder ve udun tellerini çalmak müziği dinleyen kişinin vücudunda bu sıvıların dengesini değiştirmektedir. Dört sıvı (ahlat-ı erbaa) veya humoral patoloji görüşü eski Yunan'dan alınmıştır. Kısaca söz etmek gerekirse, Insanın Doğası Üzerine adlı yazılı eserinde Hipokrat (M.Ö. 460 - 370) insan bedeninin dört sıvıdan - kan, balgam, sarı safra ve kara safra - meydana geldiğini ve bu sıvılar arasındaki dengenin bozulmasıyla hastalıkların ortaya çıtı̆̆ını ileri sürer (Mann 1983). Hipokrat'in bu humoral patoloji teorisi Galen (M.S. 129 - 200/216) tarafindan kabul edilerek yayılmış ve hücre teorisine kadar yaklaşık 2000 yıl boyunca tıbbi tedavi uygulamaları üzerine etkili olmuştur (Stelmack 1991). Galen'den etkilenen El Kindî ve İbni Sina gibi hekimlerin de dört sıvı görüşünü geliştirerek kullandıkları görülmektedir. El Kindî udun dört telinden zîr telinin sarı safray1, mesna telinin kan1, mesles telinin balgamı ve bam telinin kara safrayı arttırdığını ileri sürer (Wright 2010). Yani, hekim hastalığın hangi sıvı azlığına bağlı olduğunu düşündüyse, o sıvıyı arttıracak tel üzerinden müzik terapi uygulamaktadır. İlginç olan, bağırsak veya ibrişimden yapılan bu tellerden bam telinin siyah, mesles telinin beyaz, mesna telinin kırmızı ve zîr telinin sarı renkli olmasıdır (Turabi 1996, s.70-71). Basitçe, el-Kindî hangi telin hangi vücut sıvısını etkilediğini belirlerken telin renginden ilham almış görünüyor. Ancak, el-Kindî’nin tasarladığı müzik ve sağlık ilişkisi bu kadar basit değildir. Tarif ettiği müzik makamlarını ve melodileri tarabî (oyun ve eğlenceye uygun), hamasî (atılganlık ve güce uygun) ve kederli (hüzün ve yas tutmaya uygun) olmak üzere üç gruba ayırmıştır (Turabi 
1996, s.85). Diğer yandan müzik usullerini günün vakitleri ve duygulanımlarla eşleştirmiştir. Örneğin, öğle vaktinde mahurî gibi atik ve güçlü ritimleri, gün sonunda hezec, hafif gibi neşeli ritimleri, uyku öncesi ise uzun sakil gibi kederli ritimleri uygun görmüştür (Turabi 1996, s.80-81). Son olarak, İbnü'l Kıftî'nin İhbârü'l- 'ulemâ bi-ahbâri'l-hükemâ eseri gibi diğer kaynaklarda el-Kindî’nin hastalarını tedavi etmede müzik girişimleri kullandığını anlatan hikâyelerin bulunması onu yazılı müzik terapi geleneğimizin başlangıç noktasına koymamız için yeterli olmaktadır.

\section{İhvân-ı Safâ (9yy-10yy)}

Kollektif çalışmanın önemli simgelerinden biri olan bu topluluk, bir grup aydın ve düşünürün bir araya gelmesiyle Basra civarında ortaya çıkmıştır. Kendilerine "arınmış veya temiz gönüllü kardeşler" anlamına gelen İhvân-1 Safâ adını vermişlerdir. Birlikte kaleme aldıkları 52 risâle içinde 5 numaralı olan risâle "müzik üzerine"dir. Bu risâlede yer alan konular arasında seslerin uyumu ve uyumsuzluğu, mizaçların seslerden etkilenmesi, organların musiki prensipleriyle uyumu ve nağmelerin türlü tesirleri sayılabilir (Turabi 2012). El Kindî'de yer alan udun tellerinin arttırdığ 1 sıvılara ek olarak İhvân-1 Safâ'nın musiki risâlesinde udun tellerinin azalttığı sıvılardan da söz edilmiştir (Wright 2010, s.44). Örneğin, udun zîr teli sarı safrayı arttırmakta ve balgamı azaltmaktadır. Diğer yandan mesna teli kanı arttırırken kara safrayı azaltmaktadır. En tiz sese sahip tel (zîr) ateş elementine karşılık gelirken, en pest sese sahip tel (bam) toprak elementine karş1lık gelmektedir. İhvân-1 Safâ topluluğunun da müzik terapi anlamında aktardığı bilgi Galenik humoralizme dayanmakta, hastalıkların vücuttaki dört sıvı arasındaki düzensizlikten kaynaklandığı ve udun uygun tellerinin bu sivılar üzerine etki etmesiyle yeniden dengenin sağlandığı ve hastalığın düzeldiği ifade edilmektedir. Ancak, el-Kindî'nin teorisi genişletilmiş ve udun tellerinin etkisiyle artan sıvilara, azalan sıvılar da eklenmiştir (Tablo 1).

Tablo 1. İhvân-1 Safâ ve el-Kindi'de udun telleri ile vücut sıvıları arasındaki ilişki

\begin{tabular}{lll}
\hline & El-Kindi ve İhvân-ı Safâ & İhvân-ı Safâ \\
\hline Udun teli (ve rengi) & Güçlendirdiği sıvı & Zayıflattığı sıvı \\
\hline Zîr (sarı) & Sarı safra & Balgam \\
Mesna (kırmızı) & Kan & Kara safra \\
Mesles (beyaz) & Balgam & Sarı safra \\
Bam (siyah) & Kara safra & Kan \\
\hline
\end{tabular}

\section{Farabî (872 - 952)}

Müzik terapi tarihimizin çok önemli kaynaklarından biri olan ünlü Türk filozofu Farabî el-Mûsîka'l Kebir (930 civarında yazıldığı düşünülmektedir) kitabında müzik makamlarının en etkili olduğu vakitler ve insan ruhuna etkilerinden söz etmektedir. Farabî'nin makamlar ve etkileri listesi birçok kaynakta aktarıma dayalı olarak yer almıştır. Ancak, günümüz Türkçesine çevrimi halen beklemektedir (Arslan 2014). Kitaba ilişkin en geniş açıklamayı Türkiye Diyanet Vakfı İslam Ansiklopedisi'nde Ahmet Hakkı Turabi tarafindan yazılan el-Mûsîka'l Kebir maddesinde buluyoruz. Bu maddede Turabi'nin en önemli tespitlerinden biri Farabi'nin müzikal seslerle gök cisimleri veya sayılar arasında ilişkiler kurmadığını bildirmesidir (Turabi TDV DIA Cilt 31, sayfa 256-257). Ahlat-1 erbaa teorisinin en azından müzik terapi alanında Farabî ile kesintiye uğraması önemli bir dönüm noktası gibi görünmektedir. Bunun yerine hicaz makamı alçak gönüllülük verir, rast makamı neşe ve huzur verir, zirgüle makamı uyku verir şeklinde açıklamalar yer almaktadır. Farabî ile birlikte, udun tellerinin yerini makam isimleri, vücut sıvılarının yerini insanın psikolojik ve duygudurum halleri almaya başlamıştır. Bu bilgiler, üzerinde düşünmek için önemli bir hareket noktası oluşturmaktadır. Günümüzde, Farabî'den hareketle belli makamların etkilerinden söz etmenin kültür mirası dışında bir anlamı yoktur. Çünkü o devirde sözü edilen "makam”ın bugün anladığımız şekliyle var olduğunu söylemenin imkânı yoktur. Bugün elimizdeki makamlar hem sayıca hem de yapı olarak çok daha kapsamlıdır. Diğer yandan geleneksel müziğimizi sadece makam seviyesine indirmek, usul, form, icra, melodik gelişim ve ritim gibi diğer müzikal unsurları dikkate almamak söz konusu değildir.

\section{Şuuri Hasan Efendi (ölümü 1693)}

Osmanlı vezirlerinden Ahmed Paşa'ya ithafen yazdığ Ta'dîlü'l-emzice (1677 y1lında yazıldığı düşünülmektedir) adlı tıp kitabında bir bölümü müzik terapi konusuna ayırmıştır (Turabi 2011). Eserinde Şuuri Hasan Efendi belli müzik makamlarının belli hastalıklara iyi geldiğini söylemektedir. el-Kindî ile başlayan yazılı kaynaklardaki geleneksel müziğimize ilişkin müzik terapi bilgisinin Şuuri ile zirveye yaklaştığını söylemek mümkündür. Önce udun dört telinin vücudun dört sıvısını güçlendirici ve zayıflatıcı etkileri şeklindeki bilgi, Farabî ile farklı makamların insan ruhuna etkileri haline dönüşmüş ve Şuuri ile hastalıkların tedavisinde makam tercihleri halini almıştır. Farabî’de neşe veren rast makamı, Şuuri'de felç illetini defetmektedir. 
Farabî'de sükûnet ve rahatlık veren hüseyni makamı, Şuuri'de kalp ve akciğer iltihabına iyi gelmektedir. Şuuri, sadece makam ve hastalık ilişkisi kurmakla kalmamış, "makam-astrolojik burç", "makam-tabiat" ilişkileri de kurmuştur. $\mathrm{Bu}$ yaklaşımlar kendisinden yaklaşık bir asır sonra gelecek hekimbaşı Gevrekzade için muhtemelen önemli bir motivasyon kaynağı olmuştur.

\section{Gevrekzade Hafiz Hasan Efendi (1727 - 1801)}

Tarihsel süreçte el-Kindî ile başlayan müzik terapi yazılı tarihimiz, hekimbaşı Gevrekzâde Hafız Hasan Efendi ile zirveye erişmiştir. Gevrekzâde'ye kadar olan dönemde ilgili yazarların kitaplarında kısım ya da bölüm olarak değinilen müzik terapi, er-Risâletü'l-musikiyye mine'ddevâi' $r$-ruhaniyye adlı eserle ilk kez müstakil bir kitapta ele alınmıştır. Bu musiki risâlesinde makamların tedavi ettiği hastalıklar, makamların burçlarla ilişkisi, ten rengi, milliyet ve mesleklerle ilişkisi anlatılmıştır. Bir başka ilginç nokta da yeme-içme arttığı için artık müziğin insan ruhuna etkisinin azaldığının ileri sürülmesidir (Turabi 2015). Gevrekzâde'nin bir diğer eseri olan Netîcetü'l-fikriyye fì-tedbîri velâdeti'lbikriyye çocuk hastalıkları ve çocuk psikiyatrisi konularını işlemekte, kitabın ikinci makalesinde müzik makamları ile çocuk hastalıkları arasında ilişkiler kurmaktadır. Görüldüğü gibi Gevrekzâde, hem müzik terapi alanına ayırdığı bir kitabı (Musiki Risâlesi) ve diğer bir kitabının (Neticetül Fikriyye) bir bölümü ile makamsal müziğimizin tedavide kullanımı konusunda en önemli yazarlardan biri konumundadir.

\section{Hacı Hâş̧im Bey (1815 - 1868)}

Hâşim Bey Edvârı veya Hâş̧im Bey Mecmuası ya da kısaca Местиа olarak bilinen eser, aslında bir müzik ve güfte kitabıdır; Sultan Abdülaziz'e ithaf edilmiştir. Kitapta makamların ve usullerin tarifi verilmiştir. Ancak, kitabın bir bölümünde makamların insanlara hangi zamanda etkili olacağından söz edilmekte ve çizimle oluşturulmuş insan figürlerinden birinin üzerinde çeşitli anatomik bölümler ile makam isimlerinin eşleştirildiği dikkati çekmektedir (Tırışkan 2000). Mecmuanın bir başka ilginç yönü de "kullanılmayan makamlar"a bir bölümün ayrılmış olmasıdır. Kullanılmayan makamlar arasında pengcgâh-1 zaid, mahur-1 sagir, dilküşa, nigârinek, küçek zemzeme, ramişcan, meşkube gülzâr, şevkengiz ve hisâr-1 kürdi gibi ilginç isimler yer almaktadır. Bu kitap, bildiğimiz kadarıyla Türk müziği makamlarının insan üzerine etkilerini ele alan son yazılı tarihsel kaynak olmuştur.

\section{0'li yıllar, doğum hazırlığı ve başlangıç}

Müzik terapi alanında 2000'li yıllara kadar bazı münferit girişimler olmakla birlikte asıl ivmelenmenin bu yıllarda başladığı söylenebilir. Örneğin, diş hekimi M. Sadık Yiğitbaş'ın 1972 yılında basılan Musiki ile Tedavi adlı kitabı diş hekimliği alanından bir üretim olması özelliği ile ilgi çekicidir (Yiğitbaş 1972). Yetmişli yıllardan 2000'li yıllara kadar ülkemizde müzik terapinin lokomotifi olan grup, Yrd. Doç. Dr. Rahmi Oruç Güvenç tarafından 1976 yılında kurulan Türk Musikisini Araştırma ve Tanıtma Grubu (bilinen adıyla TÜMATA) oldu. Ancak, 2000'li yıllara gelindiği zaman müzik terapi alanında çalışmalar arka arkaya gelmeye başladı. Örneğin, çeviri eserler haricinde telif eserler yayınlanmaya başladı (Tablo 2). Lisansüstü eğitimde, doktora ve yükseklisans tez çalışmalarında müzik terapi konusunun ele alınması da üniversitelerde konuya sahip çıkıldığını gösterdi. Günümüze kadar 16 yüksek lisans (Tablo 3), 7 doktora (Tablo 4) ve 7 tipta uzmanlık (Tablo 5) tezinin yapıldığı görülmektedir.

Tablo 2. Müzik terapinin doğumunu hazırlayan telif yayınlardan bazıları

\begin{tabular}{llll}
\hline Yılı & Kitabın adı & Yazarı & Yayınevi \\
\hline $\mathbf{2 0 0 5}$ & Müzikterapi: Ruh sağlığı için müzikle tedavi & Adnan Çoban & Timaş \\
$\mathbf{2 0 0 5}$ & Müzik ile Terapi & Hasan Cihat Örter & Mephisto \\
$\mathbf{2 0 0 6}$ & $\begin{array}{l}\text { Avrupa ve Türk-İ́slâm Medeniyetinde Müzikle Tedavi: Tarihi gelişimii } \\
\text { ve uygulamaları }\end{array}$ & Ahmet Şahin Ak & Ötüken \\
$\mathbf{2 0 0 6}$ & Avrupa'da müzik ile terapi & Banu Doğan & Mephisto \\
$\mathbf{2 0 0 9}$ & Makamdan Şifaya & $\begin{array}{l}\text { Levent Öztürk, Halil Erseven, M. Fadıl } \\
\text { İş Bankası Kültür }\end{array}$ & Yayınları \\
$\mathbf{2 0 1 4}$ & Müzikle Tedavinin Merkezi: Edirne Sultan II. Bayezid Darüşşifası & Enver Şengül & Edirne Valiliği Yayınları \\
\hline
\end{tabular}


Tablo 3. Müzik terapi alanında hazırlanan yüksek lisans tez çalışmaları*

\begin{tabular}{|c|c|c|c|c|}
\hline Yılı & Tez adı & Türü & Yazarı & Tez no \\
\hline 1998 & $\begin{array}{l}\text { Okul öncesi ve ilköğretim çağı çocuklarının eğitimine müzik terapisinin } \\
\text { etkileri ve faydaları }\end{array}$ & Y. Lisans & İpek Gürlük & 78278 \\
\hline 1999 & $\begin{array}{l}\text { Cerrahi girişim yapılacak vakalarda; preoperatif dönemde müzik terapi } \\
\text { ve dokunma terapisi içeren hemşirelik uygulamalarının hasta üzerindeki } \\
\text { etkilerinin araştırılması }\end{array}$ & Y. Lisans & Şengül Güngör & 91510 \\
\hline 2007 & $\begin{array}{l}\text { Mekanik ventilatör desteğinde olan hastalarda müzik terapinin } \\
\text { anksiyetenin fizyolojik belirtilerine etkisi }\end{array}$ & Y. Lisans & Esra Akın & 224704 \\
\hline 2007 & Müzikle tedavi ve öğrenciler üzerindeki terapik etkileri & Y. Lisans & Arzu Özçevik & 206896 \\
\hline 2008 & $\begin{array}{l}\text { Zihinsel engelli öğrenciler için müzik terapi yöntemine göre hazırlanan } \\
\text { sosyal beceri öğretim programının etkililiğinin incelenmesi }\end{array}$ & Y. Lisans & Deniz Çadır & 215660 \\
\hline 2010 & $\begin{array}{l}\text { Koroner anjiyografi uygulanacak hastalarda müzik terapisinin anksiyete } \\
\text { düzeyine etkisi }\end{array}$ & Y. Lisans & Meltem Vizeli & 247926 \\
\hline 2012 & Müzik terapinin cerrahi yoğun bakım hastalarının yaşam bulgularına etkisi & Y. Lisans & Bilsev Araç & 314586 \\
\hline 2013 & $\begin{array}{l}\text { Gögüs hastalıkları servisinde yatan koah hastalarında müzik terapisinin } \\
\text { anksiyete ve bazı klinik bulgulara etkisi }\end{array}$ & Y. Lisans & Dilek Horuz & 359632 \\
\hline 2014 & $\begin{array}{l}\text { Müzik terapinin huzurevinde yaşayan yaşlıların yalnızlık hissi üzerine } \\
\text { etkisi }\end{array}$ & Y. Lisans & Duygu Kurt & 359846 \\
\hline 2015 & $\begin{array}{l}\text { Stres ve anksiyete için alternatif ve tamamlayıcı bir model olarak müzik } \\
\text { terapi }\end{array}$ & Y. Lisans & Kübra Arlı & 427578 \\
\hline 2015 & Şizofrenik hastalarda müzik terapinin ruhsal durum üzerine etkileri & Y. Lisans & Suna Fındıkoğlu & 409466 \\
\hline 2016 & Masaj ve müzik terapinin yenidoğan stres ve davranışı üzerine etkisi & Y. Lisans & Sevcan Çak1 & 447453 \\
\hline 2016 & $\begin{array}{l}\text { Hematopoetik kök hücre nakli esnasında müzik terapinin kanser } \\
\text { hastalarının fiziksel ve ruhsal parametreleri üzerine etkisi }\end{array}$ & Y. Lisans & Gizem İlayda Geyik & 447256 \\
\hline 2016 & $\begin{array}{l}\text { Müzik terapinin cerrahi uygulanan 6-12 yaş arası çocuklarda anksiyete, } \\
\text { korku ve ağnı yönetimine etkisi }\end{array}$ & Y. Lisans & Özgür Bahadır & 445241 \\
\hline 2017 & Dünya'da müzik terapi tarihi ve eğitimi & Y. Lisans & Gonca Kayım & 460431 \\
\hline 2017 & $\begin{array}{l}\text { Demans - Alzheimer hastalarında farklı müzik terapi uygulamalarının zihinsel, } \\
\text { psikolojik, anksiyete ve ajitasyon etkileri üzerine karşılaştırmalı çalışma }\end{array}$ & Y. Lisans & $\begin{array}{l}\text { Emine Elif Şahin } \\
\text { Karadeniz }\end{array}$ & 460429 \\
\hline
\end{tabular}

*Bu tabloda yer alan tez çalışmalarına https://tez.yok.gov.tr/UlusalTezMerkezi/ internet adresinden erişilebileceği için ayrıca kaynaklar bölümüne eklenmemiştir.

Tablo 4. Müzik terapi alanında hazırlanan doktora tez çalışmaları*

\begin{tabular}{lllll}
\hline Yllı & Tez adı & Türü & Yazarı & Tez no \\
\hline $\mathbf{2 0 1 2}$ & $\begin{array}{l}\text { Müzik terapisinin hemodiyaliz hastalarının algıladıkları stresörler } \\
\text { ve anksiyete düzeyleri üzerine etkisi }\end{array}$ & Doktora & Işın Cantekin & 319039 \\
$\mathbf{2 0 1 2}$ & $\begin{array}{l}\text { Koroner arter bypass greft ameliyatı uygulanan hastalarda müzik } \\
\text { terapinin temel yaşam bulguları, ağrı, anksiyete ve hastanede kalış } \\
\text { sürelerine etkisi }\end{array}$ & Doktora & Yeliz Ciğerci & 326259 \\
$\mathbf{2 0 1 3}$ & $\begin{array}{l}\text { Mekanik ventilasyonlu hastanın aspirasyon işleminde uygulanan } \\
\text { müzik terapinin ağrı ve fizyolojik parametrelere etkisi }\end{array}$ & Doktora & Yeşim Yaman Aktaş & 342017 \\
$\mathbf{2 0 1 5}$ & $\begin{array}{l}\text { Kemoterapi uygulanan hastalarda müzik terapinin kemoterapi } \\
\text { semptomları ve konfor düzeyine etkisi }\end{array}$ & Doktora & Şebnem Bilgiç & 408300 \\
$\mathbf{2 0 1 5}$ & $\begin{array}{l}\text { Müzik terapisinin yaşlı kanser hastalarının anksiyete ve uyku } \\
\text { kalitesi üzerine etkisi }\end{array}$ & Doktora & Kübra Gökalp & 420232 \\
$\mathbf{2 0 1 6}$ & $\begin{array}{l}\text { Türk din mûsikîsinin sağlıklı insanların hormonal yapıları } \\
\text { üzerindeki etkileri }\end{array}$ & Doktora & Pınar Arslan & 437162 \\
$\mathbf{2 0 1 6}$ & $\begin{array}{l}\text { Müzik terapi, şiir terapi ve yaratııı drama uygulamalarının } \\
\text { üniversite öğrencilerinin benlik saygısı düzeyleri üzerine etkisi }\end{array}$ & Doktora & Esra Yücesan & 429488 \\
\hline
\end{tabular}

*Bu tabloda yer alan tez çalışmalarına https://tez.yok.gov.tr/UlusalTezMerkezi/ internet adresinden erişilebileceği için ayrıca kaynaklar bölümüne eklenmemiştir. 
Tablo 5. Müzik terapi alanında hazırlanan tıpta uzmanlık tez çalışmaları*

\begin{tabular}{|c|c|c|c|c|}
\hline Yılı & Tez adı & Yazarı & Alanı & Tez no \\
\hline 2009 & $\begin{array}{l}\text { Müzik, beyaz gürültü ve ortam gürültüsünün spinal anestezi ile } \\
\text { ameliyat olan hastalarda sedasyon ve anksiyete üzerine etkileri }\end{array}$ & Nazan Köylü İlkaya & $\begin{array}{l}\text { Anestezi ve } \\
\text { Reanimasyon }\end{array}$ & 243151 \\
\hline 2012 & $\begin{array}{l}\text { Farklı desibellerdeki çeşitli müzik türlerinin serebral oksidatif } \\
\text { hasar üzerine etkileri }\end{array}$ & Ülkühan Düzgün & Nöroloji & 303857 \\
\hline 2014 & $\begin{array}{l}\text { Müzik lisans eğitiminin dikkat eksikliği belirtileri ve çalışma } \\
\text { belleği üzerine etkileri }\end{array}$ & Bahar Yeşil & Psikiyatri & 370039 \\
\hline 2014 & $\begin{array}{l}\text { Spinal anestezi altındaki hastalara müzik dinletilmesi veya ortam } \\
\text { seslerinin engellenmesinin sedasyon ve hemodinami üzerine } \\
\text { etkileri }\end{array}$ & Mehmet Karasakal & $\begin{array}{l}\text { Anestezi ve } \\
\text { Reanimasyon }\end{array}$ & 379216 \\
\hline 2015 & $\begin{array}{l}\text { Acil servise başvuran hastalarda triajda müzik yayınının ağrı ve } \\
\text { anksiyeteye olan etkisinin araştırılması }\end{array}$ & Sami Ulusal & $\begin{array}{l}\text { İlk ve Acil } \\
\text { Yardım }\end{array}$ & 417324 \\
\hline 2015 & $\begin{array}{l}\text { Pediatrik dental girişimlerde müzik dinletilmesinin sedasyon } \\
\text { gereksinimi ve düzeyine etkisi }\end{array}$ & Özlem Özkalaycı & $\begin{array}{l}\text { Anestezi ve } \\
\text { Reanimasyon }\end{array}$ & 390264 \\
\hline 2016 & $\begin{array}{l}\text { Bel ağrısına yönelik girişimsel işlem yapılan hastalarda müzik } \\
\text { dinlemenin girişimsel analjezi ve hasta konforuna etkisi }\end{array}$ & Coşkun Çifci & $\begin{array}{l}\text { Anestezi ve } \\
\text { Reanimasyon }\end{array}$ & 437543 \\
\hline
\end{tabular}

*Bu tabloda yer alan tez çalışmalarına https://tez.yok.gov.tr/UlusalTezMerkezi/ internet adresinden erişilebileceği için ayrıca kaynaklar bölümüne eklenmemiştir.

$\mathrm{Bu}$ çalışmalar müzik terapi üzerine düşünülmeye başlandığını, en azından bir grup akademisyen, doktor, sağlik profesyoneli ve müzisyenin müzik terapi ile ilgilendiğini bu alanı açmaya çalıştığını gösteriyordu. Makamdan şifaya kitabının yayınlanmasından hemen sonra aynı grup 5 yıl civarında süren terapi müzikleri konserlerine başladı. Bu konserler iki bölümden oluştu. İlk bölümde yapılan mini konferansta Türk Müzik Terapi geleneği anlatılıyor, daha sonra da yapılandırılmış iki bölüm halinde terapi müzikleri icrası yapılıyordu. İlk bölüm "uyku seansı" ikinci bölüm ise "enerji seansı" temasını işliyordu. Makamdan şifaya konserleri bir kamuoyu oluşturulmasına ve konunun gündemde tutulmasına önemli katkı sağladı. Kitaplar ve konserler yanı sira bilimsel toplantı ve sempozyumlarda müzik terapi konusu işlenmeye başlandı. Hatta yine Öztürk'ün girişimiyle 2008 yılında Trakya Üniversitesi Tıp Fakültesi'nde seçmeli ders olarak müzikle tedavi dersi açıldı. Dersin amacı geleceğin doktorlarına daha öğrencilikleri döneminde müzik terapi konusunda açılış bilgilerini vermek ve bu uygulamanın kanıta dayalı tıp uygulamaları içinde giderek yerini aldığını anlatmaktı. 2014 y1lından itibaren İstanbul Medipol Üniversitesi Tip Fakültesi'nde Prof.Dr. Hanefi Özbek tarafından Farmakoloji dersi müfredatına, Yrd. Doç. Dr. Mahmut Tokaç tarafından Tıp Tarihi ve Deontoloji dersi müfredatına Geleneksel ve Tamamamlayıcı Tıp Uygulamaları ana başlığı altında müzik terapi konusu dahil edildi.

Bireysel çalışmaların hız kazandığı bir dönemde bazı önemli yasal düzenlemeler sürecin gelişmesine ciddi katkıda bulundu. 2 Kasım 2011 tarih ve 28103 sayılı Resmi Gazete'de yayımlanan 663 sayılı KHK (Kanun Hükmünde Kararname) ile Sağlık Bakanlığ Sağlık Hizmetleri Genel Müdürlüğü'ne "Geleneksel, tamamlayıcı ve alternatif tıp uygulamaları ile ilgili düzenleme yapmak" yetkisi verildi. Buna dayanarak hazırlanan Geleneksel ve Tamamlaylcr Tip Uygulamaları Yönetmeliği 27 Ekim 2014 tarih ve 29158 sayılı Resmi Gazete'de yayınlanarak yürürlüğe girdi. $\mathrm{Bu}$ yönetmelikte düzenlenen 15 uygulamanın (akupunktur, apiterapi, fitoterapi, hipnoz, sülük uygulamas1, homeopati, kayropraktik, kupa uygulamas1, larva uygulamas1, mezoterapi, proloterapi, osteopati, ozon uygulaması, refleksoloji) sonuncusu müzik terapi oldu. Yönetmeliğin ardından bu uygulamaları yapacak profesyonellerin yetiştirilmesi çalışmaları hızla başladı. Yönetmelik gereğince Sağlık Bakanlığı Sağlık Hizmetleri Genel Müdürlüğü bünyesinde oluşturulan Geleneksel ve Tamamlayıcı Tip Uygulamaları Bilim Komisyonunda, komisyonun asil üyelerine alt komisyonları kurma ve eğitim programı standartlarını hazırlama hususunda görev dağılımı yapıldı. Bu görev kapsamında, Prof.Dr. Hanefi Özbek'in başkanlığında müzik terapi alt çalışma grubu kuruldu. Alt komisyonun üyeleri Prof.Dr. Hanefi Özbek, Prof.Dr. Levent Öztürk, Doç.Dr. Burçin Uçaner, Yrd. Doç. Dr. Rahmi Oruç Güvenç, Yrd. Doç. Dr. Ömer Hakan Yavaşoğlu, Uzm. Dr. Diğdem Albasan ve Muharrem Fadıl Atik’ten oluşmaktaydı. Alt çalışma grubu tarafından hazırlanan Sertifikalı Eğitim Programı Standartları 13 Temmuz 2016 tarihinde Sağlık Hizmetleri Genel Müdürlüğü Geleneksel ve Tamamlayıcı 
Tıp Uygulamaları Daire Başkanlığı'nın internet sayfasında yayımlandı. Bu çalışmalar sayesinde artık her şey hazırdı. Sağlık Bakanlığı tarafindan verilecek müzik terapist sertifikaları ile bu alan resmi olarak yeniden başlatılmış olacaktı. Gerçekten de, aynı yılın sonuna doğru ilk değerlendirmeler sonucunda 10 kadar kişiye müzik terapist sertifikası verildi. Prof. Dr. Hanefi Özbek, Prof. Dr. Şükrü Torun ve Prof. Dr. Levent Öztürk Cumhuriyet tarihinin ilk "müzik terapist" sertifikalı tıp doktorları olarak kayda geçtiler. Sertifika alan ilk grup içinde müzikoloji alanından Doç. Dr. Burçin Uçaner Çiftdalöz, psikoloji alanından Yrd. Doç. Dr. Sibel Doğan ve müzik alanından M. Fadıl Atik de yer aldi.

\section{Geleneksel ve Tamamlayıcı Tıp Uygulamalarının Klinik Araştırmaları Hakkında Mevzuat}

Müzik terapi ile birlikte diğer Geleneksel ve Tamamlayıcı Tıp Uygulamalarının bilimsel araştırmalarla kanıta dayalı olarak da etkililiklerinin gösterilmesi önemli bir husustur. Böylece halihazırda yapılmakta olan uygulamaların güvenilirliğinin bilimsel bakış açısıyla yeniden değerlendirilmesi yanında bunların bilimsel yöntemlerle daha da geliştirilmesi ve yeni uygulama yollarının bulunarak hizmete sunulması mümkün olacaktır. Ancak ülkemizde Geleneksel ve Tamamlayıcı Tıp Uygulamalarının klinik araştırmaları hakkında bir mevzuat boşluğu bulunmaktadır. İlgili diğer mevzuatın bu boşluğu yeterince dolduramamasının yanında, birçok bilim adamı ve bazı etik kurulların bu tür araştırmalara olumsuz tavır alması yüzünden bu alanlardaki bilimsel araştırmalar sekteye uğramakta, bilim adamlarının çalışma şevki kırılmaktadır. Buradaki mevzuat boşluğunu doldurmak amacı ile Sağlık Hizmetleri Genel Müdürlügü’nün bilgisi dâhilinde Prof. Dr. Hanefi Özbek tarafından hazırlanan Geleneksel ve Tamamlayıcı Tıp Uygulamalarının Klinik Araştırmaları Hakkındaki Yönetmelik taslağı, ilgili tüm kurum ve kuruluşlardan görüş alma aşamasından geçmiş olup Sağlık Bakanlığı tarafından yayımlanma aşamasına gelmiştir. Etik düzenleme ile birlikte müzik terapi ve diğer uygulamaların yer aldığı araştırma çalışmalarında etik inceleme aşaması düzenlenerek bu çalışmaların hız kazanması sağlanacaktır.

\section{Kurumsallaşma ve ilk müzik terapi dernekleri}

Müzik terapinin güçlü biçimde varlığını sürdürmesinin kurumsallaşma ile sağlanabileceği kısa sürede anlaşıldı. 2014 yılında Doç. Dr. Burçin Uçaner başkanlığında Müzik
Terapi Derneği (MÜZTED) ve 2016 yılında Prof. Dr. Levent Öztürk başkanlığında Uygulamalı Müzik Terapileri Derneği (UMTED) kuruldu. Her iki dernek de müzik terapinin ülkemizde gelişmesi adına kısa sürede işbirliği içinde çalışmaya başladı ve aktiviteleri birlikte desteklemeye başladılar. MÜZTED kitap çevirileri, konferanslar ve atölye çalışmaları ile müzik terapi farkındalığını arttırmaya çalışırken UMTED ilk geleneksel müzik terapi kursunu 28 Ekim 2017'de Edirne'de gerçekleştirdi.

\section{Sonuç}

Müzik terapi uygulamaları yaşadığımız coğrafyada 800 'lü yıllardan itibaren yazılı kaynaklara girmiş ve 1800 'lü yıllara kadar dönemin tıp ve sağlık görüşleri içinde gelişerek, dönüşerek kullanılagelmiştir. 1850'li yıllarda terk edilen veya unutulan bu uygulamalar son on y1l içinde özellikle yoğunlaşan çalışmaların katkısı ve Devlet kurumlarının bu konudaki desteği ile yeniden başlatılmış, âdeta küllerinden yeniden doğmuştur. İleriye dönük hedefler içinde kurumsallaşan müzik terapinin güçlendirilmesi, müzik terapistlerin mesleklerini daha rahat uygulayabilecekleri ortamların ve yasal düzenlemelerin geliştirilmesi, müzik okur-yazarlığının geliştirilmesi, müzik terapi uygulamalarının sigorta kapsamına alınması ve geleneksel müziğimizin bu alandaki potansiyelinin geliştirilmesi gibi konular yer alabilir. Kesin olan bir şey var, o da müzik terapi alanının kendi gönüllülerini bekliyor olduğudur.

\section{KAYNAKLAR}

1. Cihan AK. Bilimler tasnifi ve İbni Sina. Erciyes Üniversitesi Sosyal Bilimler Enstitüsü Dergisi 2000;9:435-451

2. Adamson P. Great medieval thinkers: Al-Kindi. Oxford University Press 2007, p.173

3. Mann WN (Çeviri). On the nature of man. In: Lloyd G.E.R. (Ed), Hippocratic writings (pp.260-271). Harmondsworth: Pelican classics (orijinal çalışmanın yazım tarihi yaklaşık M.Ö. 460).

4. Stelmack RM, Stalikas A. Galen and the humour theory of temperament. Person Individ Diff 1991;12(3):255-263

5. Wright O. Epistles of the brethren of purity: On music, An Arabic critical edition and English translation of Epistle 5. Oxford University Press, Islamic Publications Ltd. 2010, p. 16 ; s.44

6. Turabi AH. El-Kindî'nin mûsikî risâleleri (Yüksek Lisans Tezi). Marmara Üniversitesi Sosyal Bilimler Enstitüsü İslâm Tarihi ve Sanatları Bölümü, Türk Din Musikisi Anabilim Dal1. İstanbul 1996, s.70-71; s.80-81; s.85 
7. Turabi AH (çeviri). Matematik kısmının beşinci risâlesi: Musiki. Kahraman A (Editör), İhvân-1 Safâ risâleleri cilt 1, Ayrınt1 Yayınları İstanbul 2012, s.129-160

8. Arslan F. Müslüman-Türk bilginlerin müzik bilimine katkıları (X-XIII.yüzyıllar). Türkiyat Mecmuası 2014, C24/ Güz:1-21

9. 9-http://www.islamansiklopedisi.info/dia/pdf/c31/c310176. pdf

10. Turabi AH. Hekim Şuûrî Hasan Efendi ve Ta'dîlü'l-Emzice adlı eserinde müzikle tedavi bölümü. M.Ü. İlâhiyat Fakültesi Dergisi 2011;40:153-166

11. Turabi AH. Gevrekzâde, müzikle tedavi, Amasya Darüşşifa örneği. Amasya Belediyesi Kültür Yayınları, Amasya 2015, s.38

12. Tırışkan AG. Hâşim bey edvârı (Yüksek lisans tezi). İstanbul Teknik Üniversitesi Sosyal Bilimler Enstitüsü Güzel Sanatlar Anadalı, Türk Sanat Müziği Alanı. İstanbul 2000
13. Yiğitbaş MS. Musiki ile tedavi. Yelken Matbaası, İstanbul 1972

14. Çoban A. Müzikterapi: Ruh sağlığı için müzikle tedavi. Timaş Yayınları, İstanbul 2005

15. Örter HC. Müzik ile terapi. Mephisto Yayınları, İstanbul 2005

16. Ak AŞ. Avrupa ve Türk-İslâm Medeniyetinde Müzikle Tedavi: Tarihi gelişimi ve uygulamaları. Ötüken Yayınları, İstanbul 2006

17. Doğan B. Avrupa'da müzik ile terapi. Mephisto Yayınlar1, İstanbul 2006

18. Öztürk L, Erseven H, Atik MF. Makamdan şifaya. İş Bankası Kültür Yayınları, İstanbul 2009

19. Şengül E. Müzikle Tedavinin Merkezi: Edirne Sultan II. Bayezid Darüşşifası. Edirne Valiliği Yayınları, Edirne 2014 